\title{
Efficiency and Stability of Exopolysaccharide Production from Different Carbon Sources by Erwinia herbicola
}

\author{
By J. D. LINTON, ${ }^{*} \dagger$ D. GOULDNEY AND S. WOODARD \\ Shell Research Ltd, Sittingbourne Research Centre, Sittingbourne, Kent ME9 8AG, UK
}

(Received 25 January 1988)

\begin{abstract}
Under conditions of glucose limitation the maximum yield of Erwinia herbicola from oxygen $\left(Y_{\mathrm{O}_{2}}^{\max }\right)$ and glucose $\left(Y_{\mathrm{glc}}^{\max }\right)$ was $31 \mathrm{~g} \mathrm{~mol}^{-1}$ and $72 \mathrm{~g} \mathrm{~mol}^{-1}$ respectively. This corresponded to a relative ATP/O quotient between $1 \cdot 1$ and $1 \cdot 5$. The cytochrome profile indicated the absence of $c$-type cytochromes which is consistent with this low ATP/O quotient. During nitrogen-limited growth on glucose, the rate of polysaccharide production $\left(0.34-0.37 \mathrm{~g} \mathrm{~g}^{-1} \mathrm{~h}^{-1}\right)$ was independent of growth rate, whereas the rate of production of gluconate and 2-ketogluconate increased with growth rate. The ATP/O quotient of 1.25 derived from glucose-limited growth was used to calculate the theoretical yields of exopolysaccharide from fructose and oxygen. The values obtained were close to the observed yields once an allowance had been made for cell production. Thus the growth efficiency of $E$. herbicola appears to be unaltered during carbon- or nitrogenlimited growth on fructose. At an ATP/O quotient of 1.25 the synthesis of the acid moiety of the exopolysaccharide provides a significant proportion (51-65\%) of the ATP needed for polymerization of the sugar backbone. Nevertheless, the rate of ATP turnover is large in relation to that required for cell production under these conditions. Polymer production may serve as a means of turning over ATP but it is not essential for growth as mutants that do not produce exopolysaccharide but turnover ATP by some other means are readily selected. The rate of ATP turnover rather than exopolysaccharide production appears to be physiologically important.
\end{abstract}

\section{INTRODUCTION}

Microbial exopolysaccharides have considerable commercial potential (Sandford, 1979; Kang et al., 1983). Although there have been many publications on xanthan and alginate production very few are concerned with the energetics and physiology of both exopolysaccharide and microbial biomass production. Without some estimation of the growth efficiency of the producing organism the energetics of exopolysaccharide production cannot be determined with any confidence.

In methylotrophic micro-organisms the energetic constraints imposed by the various pathways of $\mathrm{C}_{1}$ assimilation appear to strongly influence both the rate of synthesis and the composition of exopolysaccharide produced (Linton et al., 1986).

In Agrobacterium radiobacter NCIB 11883 there is more than a casual link between the chemical composition of the exopolysaccharide produced and the energetic efficiency extant in this organism (Linton et al., 1987a). Because of the ATP/O quotient present in this organism approximately $60 \%$ of the energetic demand for polymer synthesis is actually supplied as a result of the production of the acid moieties that comprise the exopolysaccharide. Thus the net ATP demand for polymer production is reduced; however, the overall rate of ATP turnover is very high and may amount to between 60 and $90 \%$ of that required for cell production under these conditions. In $A$. radiobacter exopolysaccharide production appears to function as an effective means of turning over ATP as the respiratory activity over and above that required for cell

† Present address: Koninklijke Shell Laboratorium, Badhuisweg 3, 1003 AA Amsterdam, The Netherlands. 
production could be accounted for in terms of exopolysaccharide production during nitrogenlimited growth on glucose (Linton et al., 1987a,b). In this paper 'ATP turnover' is defined as the synthesis of ATP and its subsequent hydrolysis by various means including exopolysaccharide production.

In order to determine whether the link between polymer composition and energetic efficiency (ATP/O quotient of carbon-limited cultures) of the producing organisms is a general phenomenon we have examined exopolysaccharide production by an organism unrelated to those previously studied. Erwinia herbicola was chosen because it produces a highly acylated exopolysaccharide at a high specific rate.

\section{METHODS}

Organism. The organism used in this study was isolated from the gummy exudate of a Victoria plum by direct plating onto mineral salts agar containing a pH indicator, $1 \%$ glucose and sodium nitrate as the sole source of nitrogen. The isolate was observed as small colonies that excreted substantial levels of acidic metabolites that changed the $\mathrm{pH}$ indicator from green to yellow. In mineral salts medium, growth in shake flask culture was accompanied by the excretion of gluconate and 2-ketogluconate. This organism has been characterized by the National Collection of Industrial Bacteria (Aberdeen, UK) as being a member of the 'Erwinia herbicolaEnterobacter agglomerans' complex and deposited as NCIB 12495. In this paper the organism is referred to as Erwinia herbicola.

Media. Cultures were maintained on yeast extract agar containing $10 \mathrm{~g}_{\text {glucose }} \mathrm{l}^{-1}+3 \mathrm{~g} \mathrm{CaCO}_{3} \mathrm{I}^{-1}$. In the absence of $\mathrm{CaCO}_{3}$ the cultures lost viability rapidly because of rapid acidification of the culture medium. The medium used for continuous culture studies was described previously (Linton et al., 1987a); however a chelator was not used.

Continuous culture. Continuous culture studies were done in a Biotec fermenter as described previously (Linton et al., 1986). Nutrient limitation was established by ensuring that there was a proportional increase in cellular biomass when the concentration of the limiting nutrient was increased. Thus the steady state bacterial dry weight was found to be directly proportional to the glucose input concentration over the range $1-6 \mathrm{~g} \mathrm{I}^{-1}$ and the molar growth yield was independent of the input glucose concentration. This medium has been shown to be capable of supporting carbon-limited growth at a cell density of at least $4 \cdot 5 \mathrm{~g}$ dry wt $\mathrm{l}^{-1}$ (Linton et al., 1987a).

Analyses. Oxygen uptake and $\mathrm{CO}_{2}$ output from the chemostat culture was continuously measured using a paramagnetic analyser (type OA 184, Servomex) and an infra-red analyser (MSA Instruments) respectively.

Glucose concentrations in the effluent culture media of carbon-limited cultures were determined by the glucose oxidase method. The carbon contents of total culture, cell-free supernatants and medium input samples were determined using a Beckman 915-B Total Organic Carbon Analyser. The ammonia concentration in culture input and effluent media was determined using a Technicon Autoanalyser II (Technicon Industrial Method no. 108-70 W). Acetate contents of culture supernatants were determined by gas-liquid chromatography using a Varian 1400 series chromatograph fitted with a Poropak-Q column at $210^{\circ} \mathrm{C}$. The concentrations of glucose, gluconate and 2-ketogluconate in culture supernatants were determined by HPLC using the method described previously (Linton et al., 1987a).

Exopolysaccharide determination. The exopolysaccharide produced was degraded if left in contact with the cells as was evident by the rapid loss of viscosity. Consequently, rapid centrifugation followed by heating of the culture supernatant at $\mathrm{pH} 7 \cdot 0$ to $70{ }^{\circ} \mathrm{C}$ for $20 \mathrm{~min}$ was necessary to prevent this hydrolysis. The addition of propan-2-ol did not result in precipitation of the polymer. In order to determine the concentration of exopolysaccharide, supernatants were dialysed for $3 \mathrm{~d}$ before known volumes were dried to constant weight.

Chemical composition of exopolysaccharide. Freeze-dried polymer $(20 \mathrm{mg})$ was heated to $95{ }^{\circ} \mathrm{C}$ for $16 \mathrm{~h}$ with $0.5 \mathrm{M}$ $\mathrm{H}_{2} \mathrm{SO}_{4}$ in a sealed tube; the resulting hydrolysate was divided into two portions, one of which was used for the determination of sugars and the other for the determination of the organic acid content. Sugars and acids were determined by HPLC (Linton et al., 1987a). The uronic acid content of the exopolysaccharide was determined by the method of Blumenkrantz \& Asboe-Hansen (1973) using D-glucuronic acid and glucuronic acid lactone as standards.

The results of the three different analyses were summed and expressed as a percentage $(w / w)$ of the starting material; only those samples that gave a combined recovery of $>85 \%$ were used.

\section{RESULTS}

\section{Growth efficiency during glucose limitation}

Before the energetics of exopolysaccharide production could be studied it was necessary to estimate the efficiency of energy conservation of the producing organism. E. herbicola was therefore grown under glucose limitation at various dilution rates and the yields from glucose 


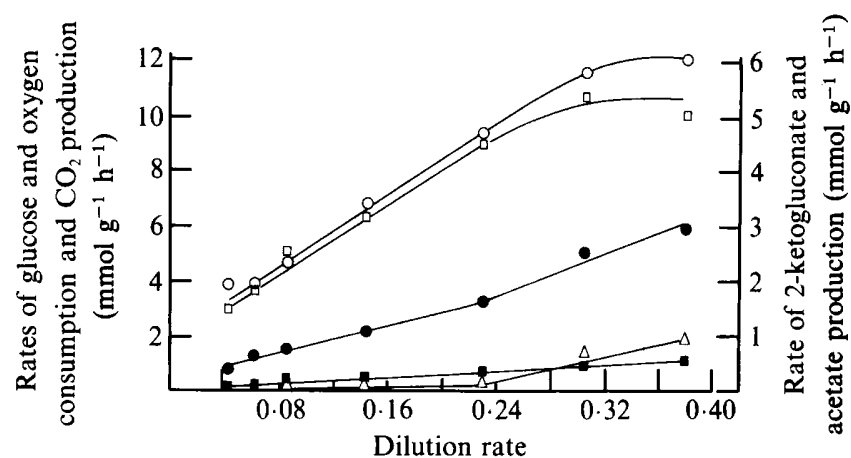

Fig. 1. Effect of growth rate on the specific rate of glucose and oxygen consumption and the production of $\mathrm{CO}_{2}, 2$-ketogluconate and acetate by a glucose-limited chemostat culture of $E$. herbicola run at $30^{\circ} \mathrm{C}$, $\mathrm{pH}$ 7.0. Rates of oxygen $(\mathrm{O})$ and glucose $(O)$ consumption and the production of $\mathrm{CO}_{2}(\square), 2$ ketogluconate $(\mathbf{Q})$ and acetate $(\triangle)$ are shown.

Table 1. Effect of growth rate on the yield from glucose and oxygen and the production of gluconate, 2-ketogluconate and exopolysaccharide by a glucose-limited chemostat culture of E. herbicola growing at $30^{\circ} \mathrm{C}, \mathrm{pH} 7 \cdot 0$

Values for the fructose-limited culture are in bold type.

\begin{tabular}{|c|c|c|c|c|c|c|c|c|}
\hline Dilution rate $\left(\mathrm{h}^{-1}\right)$ & 0.04 & 0.06 & 0.09 & $0 \cdot 14$ & 0.23 & $0 \cdot 31$ & $0 \cdot 38$ & $0 \cdot 10$ \\
\hline $\begin{array}{r}\text { Glucose }\left(\mathrm{g} \mathrm{l}^{-1}\right) \text { input } \\
\text { output }\end{array}$ & $\begin{array}{r}5.73 \\
<0.02\end{array}$ & $\begin{array}{c}6.1 \\
<0.02\end{array}$ & $\begin{array}{c}3.9 \\
<0.02\end{array}$ & $\begin{aligned} & 6 \cdot 0 \\
< & 0.02\end{aligned}$ & $\begin{array}{c}6 \cdot 1 \\
<0 \cdot 02\end{array}$ & $\begin{aligned} & 6.0 \\
< & 0.02\end{aligned}$ & $\begin{aligned} & 5.6 \\
< & 0.02\end{aligned}$ & $\begin{array}{r}6 \cdot 3 \\
<\mathbf{0 \cdot 0 2}\end{array}$ \\
\hline $\begin{array}{l}\text { Bacterial dry wt }\left(\mathrm{g} \mathrm{l}^{-1}\right) \\
\text { Bacterial protein } \\
\text { content, } \% \\
(\% \mathrm{~N} \times 6.25)\end{array}$ & $\begin{array}{l}1.79 \\
71.2\end{array}$ & $\begin{array}{c}1 \cdot 65 \\
71 \cdot 8\end{array}$ & $\begin{array}{l}1 \cdot 22 \\
73 \cdot 1\end{array}$ & $\begin{array}{l}2 \cdot 21 \\
74 \cdot 3\end{array}$ & $\begin{array}{l}2 \cdot 28 \\
71 \cdot 8\end{array}$ & $\begin{array}{l}1 \cdot 98 \\
73 \cdot 7\end{array}$ & $\begin{array}{r}2 \cdot 0 \\
68 \cdot 1\end{array}$ & $\begin{array}{r}2 \cdot 1 \\
70 \cdot 6\end{array}$ \\
\hline $\begin{array}{l}Y_{\mathrm{glc}}, Y_{\mathrm{fru}}\left(\mathrm{g} \mathrm{mol}^{-1}\right) \\
Y_{\mathrm{O}_{2}}\left(\mathrm{~g} \mathrm{~mol} \mathrm{~mol}^{-1}\right) \\
\text { Extracellular products }\left(\mathrm{g} \mathrm{l}^{-}\right.\end{array}$ & $\begin{array}{l}56 \cdot 3 \\
11 \cdot 2\end{array}$ & $\begin{array}{l}49 \\
14 \cdot 8\end{array}$ & $\begin{array}{l}56 \cdot 4 \\
18.5\end{array}$ & $\begin{array}{l}66 \cdot 7 \\
21 \cdot 5\end{array}$ & $\begin{array}{l}66 \cdot 0 \\
23 \cdot 9\end{array}$ & $\begin{array}{l}60 \cdot 4 \\
26 \cdot 6\end{array}$ & $\begin{array}{l}64 \cdot 0 \\
31 \cdot 4\end{array}$ & $\begin{array}{l}60 \cdot 0 \\
20 \cdot 4\end{array}$ \\
\hline $\begin{array}{l}\text { Acetic acid } \\
\text { 2-Ketogluconate } \\
\text { Gluconate } \\
\text { Polysaccharide }\end{array}$ & $\begin{array}{l}0.014 \\
0.327 \\
0 \cdot 0 \\
0 \cdot 0\end{array}$ & $\begin{array}{l}0.021 \\
0.43 \\
0.0 \\
0.0\end{array}$ & $\begin{array}{l}0.024 \\
0.45 \\
0 \cdot 0 \\
0.0\end{array}$ & $\begin{array}{l}0.024 \\
0.54 \\
0.0 \\
0.0\end{array}$ & $\begin{array}{l}0.043 \\
0.58 \\
0.0 \\
0.0\end{array}$ & $\begin{array}{l}0.254 \\
0.54 \\
0.05 \\
0.73\end{array}$ & $\begin{array}{l}0.277 \\
0.53 \\
0.09 \\
0.83\end{array}$ & $\begin{array}{l}\mathbf{0} \\
\mathbf{0} \\
\mathbf{0} \\
\mathbf{0}\end{array}$ \\
\hline $\begin{array}{l}\text { Product carbon/ } \\
\text { supernatant carbon }(\%) \\
\text { Carbon balance }(\%)\end{array}$ & 77 & 100 & 86 & 100 & 100 & $87 \cdot 5$ & $99 \cdot 6$ & \\
\hline $\begin{array}{l}\text { Glucose carbon } \\
\text { Bacterial carbon } \\
\text { Product carbon } \\
\mathrm{CO}_{2} \text { carbon }\end{array}$ & $\begin{array}{r}100 \\
32 \cdot 8 \\
7 \cdot 6 \\
62 \cdot 7\end{array}$ & $\begin{array}{r}100 \\
29 \cdot 0 \\
6 \cdot 5 \\
49 \cdot 5\end{array}$ & $\begin{array}{l}100 \\
36 \cdot 2 \\
13 \\
55 \cdot 5\end{array}$ & $\begin{array}{r}100 \\
44 \\
8 \cdot 1 \\
48 \cdot 9\end{array}$ & $\begin{array}{r}100 \\
42 \cdot 6 \\
8 \cdot 6 \\
44 \cdot 5\end{array}$ & $\begin{array}{l}100 \\
40 \cdot 0 \\
30 \cdot 0 \\
35 \cdot 0\end{array}$ & $\begin{array}{l}100 \\
41 \cdot 2 \\
31 \cdot 7 \\
29 \cdot 7\end{array}$ & $\begin{array}{c}100 \\
38 \cdot 5 \\
10 \cdot 3 \\
49 \cdot 0\end{array}$ \\
\hline Recovery $(\%)$ & $103 \cdot 1$ & $85 \cdot 0$ & $104 \cdot 7$ & 101 & $95 \cdot 7$ & $105 \cdot 0$ & $102 \cdot 6$ & $97 \cdot 8$ \\
\hline
\end{tabular}

and oxygen were determined. During glucose-limited growth 2-ketogluconate was excreted into the culture and its specific rate of production increased with growth rate (Fig. 1). However, metabolite production was not observed when fructose was the carbon source (Table 1). At dilution rates below $0.23 \mathrm{~h}^{-1}$ growth was unequivocally glucose-limited (see Methods). At higher growth rates the availability of metal ions such as $\mathrm{Mg}^{2+}$ rather than their concentration probably limited growth, causing the production of acetate and exopolysaccharide (Fig. 1 and Table 1). The excretion of acetate was not caused by oxygen-limited growth as the dissolved oxygen tension was maintained above $30 \%$ air saturation at all dilution rates.

The molar growth yields from oxygen and glucose as a function of the dilution rate are given in Table 1. Growth yields from glucose and fructose were indistinguishable when the organism was grown at the same dilution rate. 


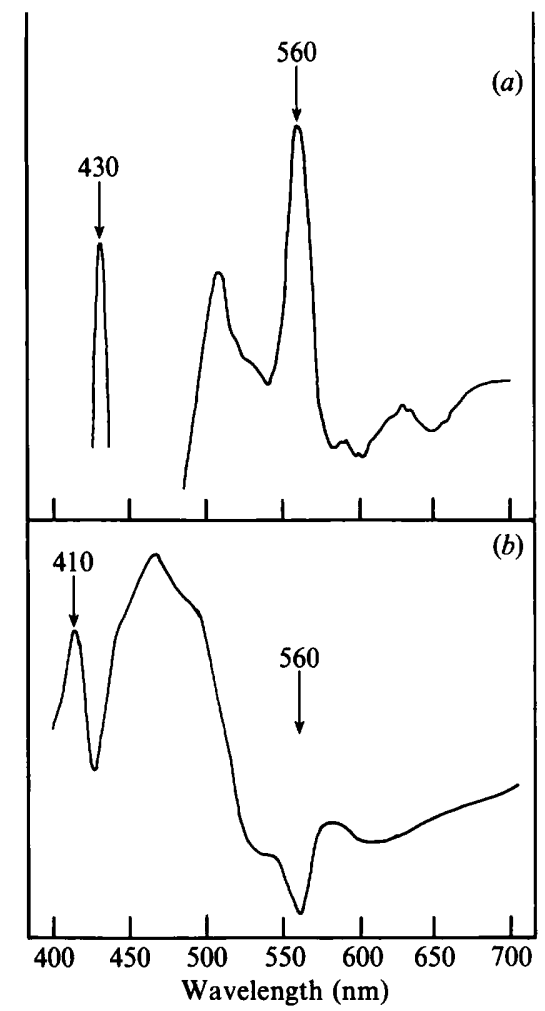

Fig. 2. Cytochrome profile of $E$. herbicola taken from a glucose-limited continuous culture run at $30^{\circ} \mathrm{C}$, pH $7 \cdot 0, D=0 \cdot 14 \mathrm{~h}^{-1}$. (a) Oxidized minus reduced difference spectra. Oxidized $\mathrm{H}_{2} \mathrm{O}_{2}$, reduced dithionite. (b) Reduced plus CO minus reduced difference spectrum.

\section{ATP/O quotient during glucose-limited growth}

The maximum yields corrected for maintenance requirements for glucose and oxygen were calculated from the slope of the $q_{\mathrm{O}_{2}}$ and $q_{\mathrm{glc}} v s$ dilution rate curves shown in Fig. 1 . The $Y_{\mathrm{O}_{2}}^{\max }$ and $Y_{\mathrm{glc}}^{\max }$ were 31.0 and $72 \mathrm{~g}$ dry wt $\mathrm{mol}^{-1}$ respectively. It is evident that the $Y_{\mathrm{O}_{2}}^{\max }$ of $31.0 \mathrm{~g}$ dry wt $\mathrm{mol}^{-1}$ is lower than that observed at $D=0.38 \mathrm{~h}^{-1}\left(31.4 \mathrm{~g} \mathrm{~mol}^{-1}\right.$; Table 1). This apparent anomaly is caused by ATP synthesis via substrate level phosphorylation as a consequence of acetate production at dilution rates $>0.23 \mathrm{~h}^{-1}$. Therefore the $Y^{\max }$ values were obtained from the slopes of the $q_{\mathrm{O}_{2}}$ and $q_{\mathrm{glc}}$ against $D$ curves at values of $D<0.23 \mathrm{~h}^{-1}$ (Fig. 1). In order to calculate the ATP/O quotient from $Y_{\mathrm{O}_{2}}^{\max }$ it was necessary to assume a value for $Y_{\mathrm{ATP}}^{\max }$. For the purpose of these calculations $Y_{\mathrm{ATP}}^{\mathrm{max}}$ values of between 12.4 and 14 determined for 'Aerobacter aerogenes' and Escherichia coli were used (Stouthamer \& Bettenhaussen, 1975; Mainzer \& Hempfling, 1976) in the equation

$$
Y_{\mathrm{O}_{2}}^{\max }=Y_{\mathrm{ATP}}^{\max } \cdot \mathrm{ATP} / \mathrm{O}
$$

It should be stressed that the ATP/O quotient of 1.1 to 1.25 mols ATP per $O$ consumed obtained is not a precise value but only a comparative yardstick of energy conservation. Nevertheless, as long as organisms growing carbon-limited on the same carbon source are compared the difference in the $Y_{A T P}^{\max }$ is minimized and the ATP/O quotient obtained will be valid as a comparative measure of growth efficiency under these conditions.

\section{Cytochrome composition}

The cytochrome complement of $E$. herbicola grown under carbon limitation consisted of cytochromes $b, a_{1}, d$ and $o$. No cytochrome $c$ was detected (Fig. 2). The absence of cytochrome $c$ is consistent with a potential ATP/O quotient of 2 (Jones, 1977; Jones et al., 1977). 
Table 2. Effect of growth rate on respiration and exocellular metabolite production from glucose by $\mathrm{E}$. herbicola grown under nitrogen limitation in continuous culture at $30^{\circ} \mathrm{C}, \mathrm{pH} 7 \cdot 0$

The non-polymer-producing mutant arose spontaneously after approximately $10-15$ residence times at $D=0.23 \mathrm{~h}^{-1}$.

Dilution rate $\left(\mathrm{h}^{-1}\right)$

Residence time in fermenter

Bacterial protein content $(\%$ dry wt)

$q_{\mathrm{glc}}\left(\mathrm{mmol} \mathrm{g}^{-1} \mathrm{~h}^{-1}\right)$

$9 \mathrm{Co},\left(\mathrm{mmol} \mathrm{g}^{-1} \mathrm{~h}^{-1}\right)$

$q_{\mathrm{O}_{2}}\left(\mathrm{mmol} \mathrm{g}^{-1} \mathrm{~h}^{-1}\right)$

$Y_{\mathrm{glc}}\left(\mathrm{g} \mathrm{mol}^{-1}\right)$

$Y_{\mathrm{O}_{2}}\left(\mathrm{~g} \mathrm{~mol}^{-1}\right)$

$q_{\text {exopolysaccharide }}\left(\mathrm{g} \mathrm{g}^{-1} \mathrm{~h}^{-1}\right)$

$q_{\text {gluconate }}\left(\mathrm{g} \mathrm{g}^{-1} \mathrm{~h}^{-1}\right)$

$q_{\text {ketogluconate }}\left(\mathrm{g} \mathrm{g}^{-1} \mathrm{~h}^{-1}\right)$

Carbon recovery $(\%)$

Product carbon accounted for $(\%)$

Gluconate $\left(\mathrm{g} \mathrm{l}^{-1}\right)$

2-Ketogluconate $\left(\mathrm{g}^{-1}\right)$

Exopolysaccharide $\left(\mathrm{g} \mathrm{l}^{-1}\right)$

Bacterial dry wt $\left(\mathrm{g} \mathrm{l}^{-1}\right)$

$\begin{array}{ccc}0.044 & 0.23 & 0.14 \text { (mutant) } \\ 6-8 & 5-10 & 17 \\ 63.75 & 70.4 & - \\ 4.58 & 11.82 & 6.53 \\ 8.7 & 10.5 & 8.71 \\ 10.7 & 20.4 & 17.5 \\ 10 \cdot 0 & 19.5 & 22.5 \\ 4.3 & 11.2 & 8.4 \\ 0.34 & 0.37 & 0.05 \\ 0.16 & 1.32 & - \\ 0.064 & 0.66 & 0.78 \\ 107 & 102 & 103 \\ 107 & 92.5 & 75 \\ 4.12 & 7.75 & - \\ 1.65 & 3.88 & 7.8 \\ 8.81 & 2.22 & 0.55 \\ 1.14 & 1.35 & 1.4\end{array}$

Table 3. Stability of exopolysaccharide production by nitrogen-limited chemostat cultures of E. herbicola growing at $30^{\circ} \mathrm{C}, \mathrm{pH} 7 \cdot 0$, with fructose or glycerol as the carbon source

\begin{tabular}{llcc}
\multicolumn{1}{c}{ Carbon source } & \multicolumn{2}{c}{ Fructose } & Glycerol \\
\cline { 2 - 3 } Dilution rate $\left(\mathrm{h}^{-1}\right)$ & 0.05 & 0.05 & 0.05 \\
Residence time in fermenter & $6-8$ & $18-20$ & $5-7$ \\
$q_{\text {sub }}\left(\mathrm{mmol} \mathrm{g}^{-1} \mathrm{~h}^{-1}\right)$ & 3.06 & 1.78 & 5.93 \\
$q_{\mathrm{CO}_{2}}\left(\mathrm{mmol} \mathrm{g}^{-1} \mathrm{~h}^{-1}\right)$ & 4.35 & $5 \cdot 16$ & 7.0 \\
$q_{\mathrm{O}_{2}}\left(\mathrm{mmol} \mathrm{g}^{-1} \mathrm{~h}^{-1}\right)$ & 4.96 & 4.97 & 8.39 \\
$Y_{\text {sub }}\left(\mathrm{g} \mathrm{mol}^{-1}\right)$ & $16 \cdot 8$ & 34.2 & 8.3 \\
$Y_{\mathrm{O}_{2}}\left(\mathrm{~g} \mathrm{~mol}^{-1}\right)$ & 10.0 & 10.0 & 5.8 \\
$q_{\text {exopolysaccharide }}\left(\mathrm{g} \mathrm{g}^{-1} \mathrm{~h}^{-1}\right)$ & 0.37 & 0.03 & 0.084 \\
$q_{\mathrm{gluconate}}\left(\mathrm{g} \mathrm{g}^{-1} \mathrm{~h}^{-1}\right)$ & 0 & 0 & 0 \\
Carbon recovery $(\%)$ & 96.1 & 96 & 103
\end{tabular}

Exopolysaccharide production from glucose during nitrogen-limited growth

The rate of exopolysaccharide production appeared to be independent of growth rate at approximately $0.34-0.37 \mathrm{~g} \mathrm{~g}^{-1} \mathrm{~h}^{-1}$ (Table 2 ). In addition to exopolysaccharide, gluconate and 2ketogluconate were excreted and their rates of production increased with dilution rate (Table 2).

\section{Exopolysaccharide production from fructose and glycerol}

Exopolysaccharide was produced from fructose and glycerol during nitrogen limitation. The $q_{\mathrm{p}}$ on the former was similar to that observed on glucose; however, on the latter it was considerably lower (Table 3 ). No other metabolites were detected during growth on these two carbon sources.

\section{Stability of exopolysaccharide production}

The $q_{\mathrm{p}}$ decreased from approximately $0.37 \mathrm{~g} \mathrm{~g}^{-1} \mathrm{~h}^{-1}$ to between 0.05 and $0.03 \mathrm{~g} \mathrm{~g}^{-1} \mathrm{~h}^{-1}$ after 17-19 fermenter residence times had elapsed in nitrogen-limited cultures with glucose and fructose respectively (Tables 2 and 3 ).

It is interesting to note that the exopolysaccharide-negative mutant selected on fructose exhibited a $q_{\mathrm{O}}$ that was similar to that of the polysaccharide-producing strain under both carbon and nitrogen limitation. However, under the latter limitation the $q_{\mathrm{fru}}$ was half that of the parent strain. 


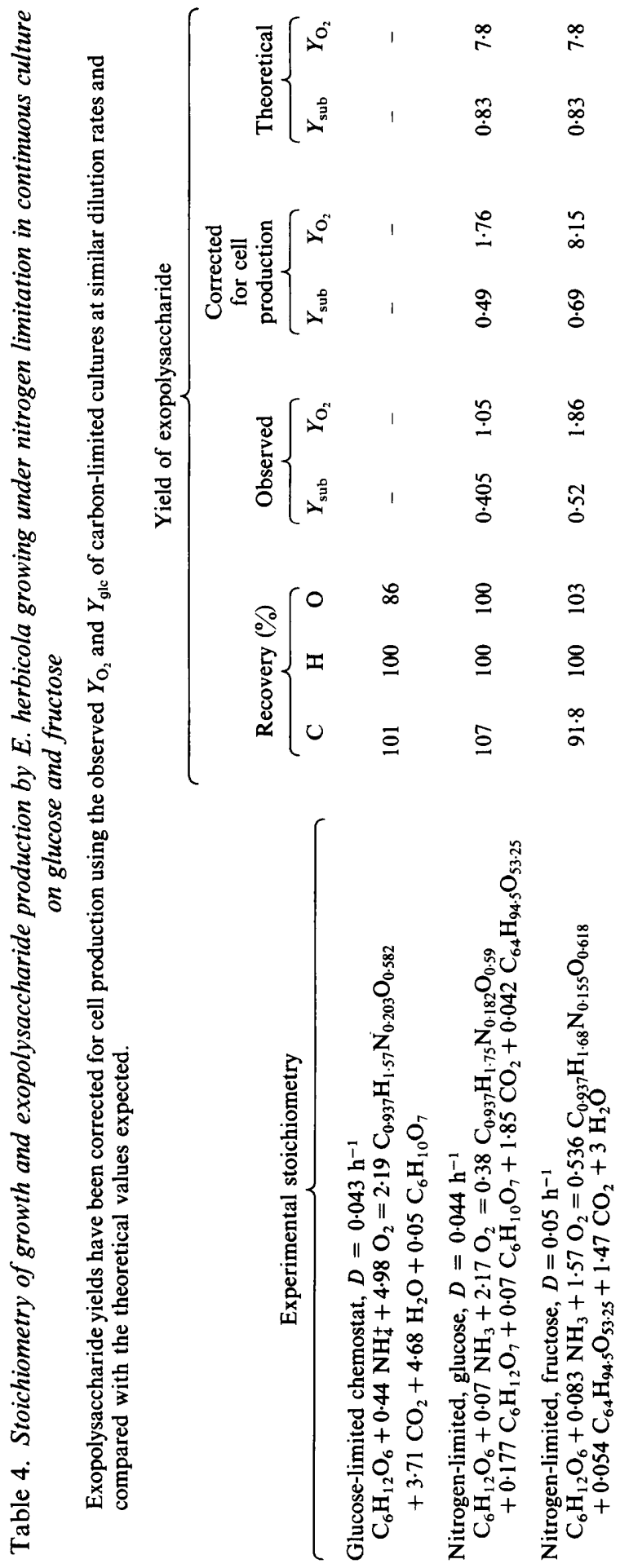




\section{Chemical composition of exopolysaccharide}

The chemical composition of exopolysaccharide was independent of carbon source. An average composition for exopolysaccharide produced from glucose was found to be galactose : glucose : acetate : succinate : pyruvate : uronic acid in the ratio $4 \cdot 26: 3: 0 \cdot 5: 1 \cdot 43$ : $1.55: 1.5$ respectively. Assuming the elimination of $1 \mathrm{~mol}$ of water per hexose polymerized and organic acid esterified a unit of succinogalactan was taken to be $\mathrm{C}_{64} \mathrm{H}_{94 \cdot 5} \mathrm{O}_{53 \cdot 25}, M_{\mathrm{r}}=1714 \cdot 5$.

\section{Mass balances for growth and exopolysaccharide production}

The amount of carbon source and oxygen consumed for cell production under carbon limitation was used to correct the observed yields of exopolysaccharide during nitrogen-limited growth on glucose and fructose (Table 4). With fructose as the carbon source the corrected yields are similar to the theoretical values calculated on the assumption that the ATP/O quotient was $1 \cdot 25$, the same as that of the carbon-limited culture. With glucose, however, the yields from oxygen are considerably lower than the theoretical values if an ATP/O quotient of 1.25 is assumed (Table 4).

\section{DISCUSSION}

The excretion of metabolites by aerobic heterotrophic bacteria during carbon-limited growth has been reported previously. For example, exopolysaccharide is produced by Xanthomonas campestris (Evans et al., 1979) and Azotobacter vinelandii (Deavin et al., 1977), and gluconate is produced by Gluconobacter oxydans (Olijve, 1978). E. herbicola also excreted metabolites during carbon-limited growth on glucose but not from fructose. The accumulation of ketogluconate in glucose-limited cultures was probably a consequence of repression of ketogluconate uptake by low residual concentrations of glucose in these cultures. At dilution rates above $0.23 \mathrm{~h}^{-1}$ growth was probably limited by some inorganic ion such as $\mathrm{Mg}^{2+}$ as has been shown for glucose-limited cultures of Beneckea natriegens (Linton et al., 1977).

\section{Energetic balance of exopolysaccharide production}

Small changes in the ATP/O quotient lead to large changes in the yield of exopolysaccharide from oxygen. The yields of exopolysaccharide from fructose corrected for cell production corresponded to that calculated with an ATP/O quotient of 1.25 , a value identical with that measured for a carbon-limited culture. With fructose therefore, the growth efficiency (ATP/O quotient) of $E$. herbicola was similar during carbon and nitrogen limitation. With nitrogenlimited glucose cultures the corrected yields were considerably lower than the theoretical (at an ATP $/ O=1.25$ ) and energetic analysis was complicated by the production of large amounts of gluconate and ketogluconate which may be associated with a change in the ATP/O quotient. For this reason further discussion of the energetics of exopolysaccharide production will be confined to production from fructose where there is evidence to support the use of ATP/O quotients derived from carbon-limited cultures.

\section{ATP generation during the synthesis of the acid substituents of the exopolysaccharide}

As the precise route of carbohydrate metabolism is not known for $E$. herbicola, the energetics of exopolysaccharide production from fructose have been calculated for metabolism via the Embden-Meyerhof (EM) and the Entner-Doudoroff (ED) pathway. 
EM pathway.

1.55 Pyruvate

0.77 Fructose +1.55 NAD $=1.55$ phosphoenolpyruvate $+1.55 \mathrm{NADH}_{2}$

0.5 Acetate

0.25 Fructose $+1 \mathrm{NAD}+0.5 \mathrm{HS}-\mathrm{CoA}=0.5$ acetyl-CoA $+1 \mathrm{NADH}_{2}+0.5 \mathrm{ATP}+0.5 \mathrm{CO}_{2}$

1.43 Succinate

1.43 Fructose + 5.72 NAD + 1.43 NADP + 1.43 HS-CoA

1.43 succinyl-CoA +1.43 ATP $+2.86 \mathrm{CO}_{2}+5.72 \mathrm{NADH}_{2}+1.43 \mathrm{NADPH}_{2}$

1.51 Uronic acid

1.51 Fructose $+1.51 \mathrm{H}_{2} \mathrm{O}+3.02 \mathrm{NAD}=1.51$ uronic acid $+3.02 \mathrm{NADH}_{2}$

Overall

3.96 Fructose + 11.29 NAD + 1.43 NADP + 1.93 HS-CoA

$=$

1.55 phosphoenolpyruvate +1.43 succinyl-CoA +1.51 uronic acid +0.5 acetyl-CoA $+3.36 \mathrm{CO}_{2}+11.29 \mathrm{NADH}_{2}+1.93 \mathrm{ATP}+1.43 \mathrm{NADPH}_{2}$

At an ATP/O quotient of $1.25,15.9 \mathrm{ATP}$ is produced via oxidative phosphorylation and 1.93 ATP via substrate level phosphorylation.

ED pathway.

Similarly, the synthesis of the acid moieties of the exopolysaccharide via the ED pathway was calculated but only the overall net reaction is given

$$
\begin{gathered}
\text { 3.96 Fructose }+3.855 \mathrm{NADP}+8.835 \mathrm{NAD}+1.93 \mathrm{ATP}+0.5 \mathrm{HS}-\mathrm{CoA} \\
= \\
\begin{array}{c}
1.55 \text { phosphoenolpyruvate }+0.5 \text { acetyl-CoA }+3.855 \mathrm{NADPH}_{2}+8.835 \mathrm{NADH}_{2}+1.43 \mathrm{CO}_{2} \\
+1.43 \text { succinyl-CoA }+1.93 \mathrm{ADP}+1.93 \mathrm{P}_{\mathrm{i}}+1.51 \text { uronic acid. }
\end{array}
\end{gathered}
$$

The ED pathway is less favourable energetically, at an ATP/O quotient of 1.25 it leads to the net production of 13.9 ATP via oxidative phosphorylation.

\section{Energetic contribution of acid constituents to overall polymer synthesis}

It has been reported that 1 ATP (or equivalent) is needed for the formation of a hexose phosphate (Sutherland, 1982; Jarman \& Pace, 1984) and a second ATP is needed for the formation of the sugar nucleotide for each hexose polymerized. A further 1 ATP is required for the attachment of the unit to the growing chain (Jarman \& Pace, 1984). The precise energetic requirements for sugar transport are unknown; consequently, it is only possible to estimate the magnitude of the impact of this process on the overall energy balance. E. herbicola is a facultative anaerobe and sugar transport is likely to occur via the phosphoenolpyruvate:sugar phosphotransferase system (Romano, 1986) which requires 1 ATP per fructose transported. Thus the total ATP requirement per unit of exopolysaccharide synthesised is approximately 27.3 ATP per unit. The contribution made by the synthesis of the acid constituents via the EM and ED pathways is approximately 65 and $51 \%$ respectively. The extent of this energetic contribution will depend on the ATP/O quotient and the reduction state of the carbon source. With glycerol, the production of a unit of exopolysaccharide via the EM pathway leads to the production of considerably more ATP than can be utilized for exopolysaccharide synthesis if the ATP/O quotient is 1.25 . Whether the considerably lower $q_{\mathrm{p}}$ supported during nitrogen limitation with glycerol is a consequence of this energy imbalance or due to some other factor such as the rate of glycerol uptake needs further investigation. A similar reduction of $q_{\mathrm{p}}$ was observed for Agrobacterium radiobacter with carbon sources that are more reduced than glucose (Linton et al., $1987 b$ ). 
As found with an exopolysaccharide-negative mutant of $A$. radiobacter (Linton et al., 1987b) the rate of fructose uptake by a nitrogen-limited culture of the exopolysaccharide-negative mutant of $E$. herbicola was considerably lower than that of the wild-type; however, the $q_{\mathrm{O}_{2}}$ of both strains were similar. The ATP/O quotient of the wild-type growing on fructose appears to be similar during carbon and nitrogen limitation. If this is also the case with the mutant, then the rate of ATP synthesis and subsequent hydrolysis ('turnover') must be similar. This suggests that the ATP turnover rate rather than exopolysaccharide synthesis is the physiologically important process under conditions of carbon excess.

\section{REFERENCES}

Blumenkrantz, N. \& Asboe-Hansen, G. (1973). New method for quantitative determination of uronic acids. Analytical Biochemistry 54, 484-489.

Deavin, L., Jarman, T. R., Lawson, C. J., RigheLATo, R. C. \& Slocombe, S. (1977). The production of alginic acid by Azotobacter vinelandii in batch and continuous culture. In Extracellular Microbial Polysaccharides, pp. 14-26. Edited by P. A. Sandford \& A. Laskin. Washington, DC: American Chemical Society.

Evans, C. G. T., Yeo, R. G. \& Ellwood, D. C. (1979). Continuous culture studies on the production of extracellular polysaccharide by Xanthomonas juglandis. In Microbial Polysaccharides and Polysaccharases, pp. 51-68. Edited by R. C. W. Berkeley, G. W. Gooday \& D. C. Ellwood. London: Academic Press.

Jarman, T. R. \& PACE, G. W. (1984). Energy requirements for microbial exopolysaccharide synthesis. Archives of Microbiology 137, 231-235.

JONES, C. W. (1977). Aerobic respiratory systems in bacteria. Symposia of the Society for General Microbiology 27, 23-59.

Jones, C. W., BRICE, J. M. \& EdWARDS, C. (1977). The effect of respiratory chain composition on the growth efficiency of aerobic bacteria. Archives of Microbiology 115, 85-93.

KANG, K. S., Veeder, G. T. \& CotTrell, I. W. (1983) Some novel bacterial polysaccharides of recent development. Progress in Industrial Microbiology 18, 231-253.

Linton, J. D., Harrison, D. E. F. \& Bull, A. T. (1977). Molar growth yields, respiration and cytochrome profiles of Beneckea natriegens when grown under carbon limitation in a chemostat. Archives of Microbiology 115, 135-142.
Linton, J. D., Watts, P. D., Austin, R. M., Haugh, D. E. \& NiekUS, H. G. D. (1986). The energetics and kinetics of extracellular polysaccharide production from methanol by micro-organisms possessing different pathways of $\mathrm{C}_{1}$ assimilation. Journal of General Microbiology 132, 779-788.

Linton, J. D., Evans, M., Jones, D. S. \& Gouldney, D. N. (1987a). Exocellular succinoglucan production by Agrobacterium radiobacter NCIB 11883. Journal of General Microbiology 133, 2961-2969.

Linton, J. D., Jones, D. S. \& WoOdard, S. (1987b). Factors that control the rate of exopolysaccharide production by Agrobacterium radiobacter NCIB 11883. Journal of General Microbiology 133, 2979-2987.

Mainzer, S. E. \& HempFling, W. P. (1976). Effects of growth temperature on yield and maintenance during glucose-limited continuous culture of Escherichia coli. Journal of Bacteriology 126, 251-256.

OlIJVE, W. (1978). Glucose metabolism in Gluconobacter oxydans. PhD thesis, Rijksuniversity of Groningen, The Netherlands.

Romano, A. H. (1986). Microbial sugar transport systems and their importance in biotechnology. Trends in Biotechnology 4, 307-313.

SANDFORD, P. A. (1979). Exocellular microbial polysaccharides. Advances in Carbohydrate Chemistry and Biochemistry 36, 265-313.

Stouthamer, A. H. \& Bettenhaussen, C. W. (1975). Determination of the efficiency of oxidative phosphorylation in continuous cultures of Aerobacter aerogenes. Archives of Microbiology 102, 187-192.

SUTHERLAND, I. W. (1982). Biosynthesis of microbial exopolysaccharides. Advances in Microbial Physio$\log y$ 23, 79-150. 